\title{
Pengaruh Supervisi Akademik Pengawas Sekolah Dan Kepemimpinan Kepala Sekolah Terhadap Kinerja Guru
}

\author{
Khoirul Khobir $^{1}$, Edi Harapan ${ }^{2}$, Nila Kesumawati ${ }^{3}$ \\ ${ }^{1 / 2}{ }^{\prime 3}$ Program Studi Manajemen Pendidikan, Universitas PGRI Palembang \\ E-mail: khoirulkhobir14@gmail.com
}

\section{Info Artikel \\ Sejarah Artikel: \\ Diterima: Agustus 2021 \\ Disetujui: September 2021 \\ Dipublikasikan: September \\ 2021 \\ Kata kunci \\ Supervisi Akademik; \\ Pengwas Sekolah; \\ Kepemimpinan; Kepala \\ Sekolah; Kinerja Guru}

Keywords:

Academic Supervision;

School Supervisor;

Leadership;

Headmaster; Teachers

Achievement

\begin{abstract}
ABSTRAK
Penelitian ini bertujuan untuk mengetahui pengaruh supervisi akademik pengawas sekolah dan kepemimpinan kepala sekolah terhadap kinerja guru. Penelitian ini dilaksanakan di SMP Negeri Se-Kecamatan Banyuasin III. Jenis penelitian ini adalah penelitian kuantitatif. Sedangkan metode peneltian yang digunakan adalah metode survei. Sampel dalam penelitian ini adalah kepala sekolah dan guru-guru SMP Negeri 1 dan SMP Negeri 2 Se-Kecamatan Banyuasin III yang berjumlah 70 orang. Teknik pengumpulan data pada penelitian ini menggunakan kuisioner. Sedangkan teknik analisis data menggunakan uji t dan uji F. Hasil penelitian ini dapat disimpulkan bahwa terdapat pengaruh supervisi akademik pengawas sekolah dan kepemimpinan kepala sekolah baik secara parsial maupun secara simultan terhadap kinerja guru SMP Negeri Se-Kecamatan Banyuasin III.
\end{abstract}

\begin{abstract}
This research aims to know the influence of school supervisors' academic supervision and headmasters' leadership to teachers' achievement. This research conducted at whole SMP Negeri in Banyuasin sub-district III. This research is quantitative research. The research method uses survey method. The samples are headmasters and teachers at SMP Negeri 1 and SMP Negeri 2 in Banyuasin subdistrict III which totally 70 people. Data collection for this research uses T-Test and F-Test. Furthermore, the result of data analysis can be concluded that there is the influence of school supervisors' academic supervision and headmasters' leadership partially and simultaneously to teachers' achievement at whole SMP Negeri in Banyuasin sub-district III.
\end{abstract}

(C) 2021 Khoirul Khobir, Edi Harapan, Nila Kesumawati Under The License CC-BY SA 4.0

\section{PENDAHULUAN}

Indonesia pada zaman kemerdekaan berupaya memberikan layanan pendidikan yang baik untuk masyarakat. Semua itu terbukti dari prestasi yang sudah diraih hingga saat ini. Namun, dibalik itu banyak masalah belum terselesaikan (Kompas. Com, diakses 15 Mei 2019). Masalah tersebut mesti memperoleh kepedulian yang sungguh-sungguh dari segenap kubu untuk meningkatkan kapasitas sumber daya manusia di Indonesia. Peningkatan kualitas sumber daya manusia (SDM) berkaitan erat dengan sistem pendidikan. Sehubungan dengan itu Bada (2012:165) menyatakan bahwa pendidikan berkualitas dapat digambarkan sebagai 
pendidikan fungsional yang menekankan baik bagian teoritis dan praktis dari sistem pendidikan. Sistem pendidikan yang berkualitas berkaitan erat pula dengan kualitas guru. Sebab menurut Harapan (2018:138) pendidikan secara universal merupakan investasi jangka panjang dalam pengembangan manusia dan utama untuk keberlanjutan bangsa dan Negara. Perlunya derajat sumber daya manusia menurut Tobari (2016:1) karena kedudukannya sebagai pelopor yang dapat membanjiri keberhasilan pencapaian tujuan secara berhasil dan praktis.

Keberhasilan suatu negara lebih kurangnya bergantung pada tingkat kinerja gurunya. Kinerja guru bergantung pada kondisi kerja dan beberapa faktor lainnya seperti mengutip pendapat (Kant, 2014:110). Sehubungan dengan pendapat di atas, menurut Sari (2014:47), minimnya mutu pendidikan nasional ini tidak terlepas dari kurangnya kinerja guru. Hal ini dikarenakan masih banyak sekolah yang kekurangan guru yang berkompeten. Hal tersebut sudah menyalahi aturan dalam UU No.14 Tahun 2005 tentang Guru dan Dosen serta PP No. 19 Tahun 2005 tentang Standar Nasional Pendidikan yakni pendidikan guru seharusnya S-1 berasal dari FKIP/IKIP. Oleh sebab itu, Salah satu upaya yang dilakukan dalam membina kecakapan kinerja guru dalam bidang akademik mesti dilakukan gerakan supervisi akademik di sekolah bagi pengawas akademik yang professional, karena menurut Srinalia (2015:195) kinerja guru mensyaratkan nilai hasil pendidikan, lantaran guru menggambarkan pihak yang banyak berinteraksi terus dengan murid dalam prosedur pembelajaran di sekolah.

Sebagaimana pada PP Nomor 74 Tahun 2008 mengenai Guru mengemukakan bahwa pengawas sekolah yaitu tenaga kependidikan yang memegang kedudukan diplomatis untuk meninggikan kadar pendidikan di sekolah dengan melakukan tugas pembimbingan, kepengawasan dan pelatihan profesional guru. Peran pokok pengawas sekolah ialah melaksanakan supervisi baik kepada kepala sekolah ataupun kepada guru sebagaimana tercantum pada PP No. 19 Tahun 2005 tentang Standar Nasional Pendidikan. Tujuan dari supervisi pengawas sekolah yaitu untuk membina dan menolong guru dalam meningkatkan mutu proses pembelajaran peserta didik.

Mutakin (2013:145) mengemukakan bahwa pada norma masyarakat Indonesia hingga detik ini, profesi guru masih lumayan tertutup. Bahkan pimpinan guru, seperti pengawas sekolah dan kepala sekolah sekalipun tidak mungkin untuk memperoleh data dan mengamati keterangan keseharian guru di hadapan siswa. Lebih lanjut dikatakan Mutakin program supervisi pengawas sekolah tidak mungkin ditolak guru. Namun, seringkali terjadi guru yang berusaha menampakkan kinerja terbaiknya hanya pada saat disupervisi. Selanjutnya, guru 
tersebut akan kembali beraktivitas seperti biasa, terkadang tanpa persiapan yang matang. Hal di atas senada dengan pendapat Tesfaw dan Hofman (2014:84) yang menyatakan bahwa guru yang memiliki lebih banyak sikap negatif terhadap supervisi seperti mempertimbangkan kegiatan pengawas untuk menjadi pencari kesalahan, guru tersebut takut bahwa pengawas akan melaporkan kelemahan administrasi sekolahnya dan percaya bahwa supervisi tidak memiliki nilai apapun kepada mereka.

Hal-hal yang telah dipaparkan di atas mampu mempengaruhi kinerja guru itu sendiri. Di sini terlihat bahwa kinerja guru menjadi suatu hal yang perlu mendapat perhatian serius oleh pengawas sekolah dan kepala sekolah. Oleh sebab itu, dibutuhkan sebuah pengawasan dan pembinaan yang dijalankan oleh pengawas sekolah dan kepala sekolah yang tujuannya ialah untuk membantu guru-guru melihat dengan nyata tujuan pendidikan itu sendiri. Oleh karena itu supervisi akademik pengawas sekolah sangat dibutuhkan untuk senantiasa mengembangkan kompetensi yang dimiliki guru terutama kinerjanya, karena kinerja bersinggungan langsung dengan proses pembelajaran dan pencapaian tujuan pendidikan.

Selain supervisi akdemik pengawas sekolah, kinerja guru juga dipengaruhi oleh kepemimpinan kepala sekolah. Berdasarkan Permendiknas No. 13 Tahun 2007 tentang Standar Kepala Sekolah, kepala sekolah yaitu guru yang diberi tugas sebagai pemimpin sekolah untuk mengendalikan sekolah, diantaranya memimpin, mengatur dan mengayomi pengikutnya serta menyelesaikan masalah-masalah yang timbul di lingkungan sekolah. Kepala sekolah bertanggung jawab terhadap maju-mundurnya kualitas pendidikan di sekolah yang menjadi tempat tugasnya. Senada seperti yang disampaikan Ahmad (2016:6) Betapa pun lengkapnya fasilitas pengajaran, namun jika kepala sekolah sebagai pelaksana tidak dapat menjalankan perannya sebagai seorang pemimpin pendidikan, maka keberhasilan pendidikan di sekolah akan susah terwujud. Kepala sekolah harus pandai mengatur dan melaksanakan pembinaan yang baik terhadap para guru sehingga berdampak pada kinerja guru dalam mencapai tujuan pendidikan.

Berdasarkan hasil bacaan peneliti dalam beberapa jurnal penelitian yang menerangkan bahwa terdapat beberapa permasalahan dalam kinerja guru di sekolah tersebut, diantaranya guru yang aktif hanya pada saat akan disupervisi saja, kurangnya minat guru dalam mengikuti pelatihan atau seminar yang berkaitan dengan perkembangan pendidikan, kurangnya minat guru dalam mempelajari teknologi dalam pendidikan, kurangnya kedisiplinan, guru belum sepenuhnya melengkapi perangkat pembelajaran, faktor usia, dan masalah pribadi. Pengawas sekolah dalam melakukan supervisi akademik sudah melaksanakan tugasnya dengan 
maksimal. Pengawas sekolah selalu menyempatkan hadir di sekolah dalam kegiatan-kegiatan seperti pada saat supervisi, rapat ataupun kegiatan lainnya. Pengawas sekolah pun sudah baik dalam membina dan membimbing kepala sekolah maupun guru dalam melaksanakan tugasnya. Kepala sekolah dalam memimpin sekolah, sudah melakukan tugas dan tanggung jawabnya dengan efektif. Kepala sekolah telah menerapkan kepemimpinan yang baik di sekolah berdasarkan keahlian kepala sekolah yang mesti dimilikinya. Kepala sekolah pun telah melaksanakan kegiatan-kegiatan rutin di sekolah dengan baik dan terencana. Kepala sekolah dalam membina dan membimbing guru juga telah melaksanakan profesinya dengan baik. Tetapi, bagaimanapun maksimalnya tugas dan kewajiban yang telah dilakukan dan diterapkan oleh pengawas sekolah dan kepala sekolah, masih saja ada guru yang masih memiliki kinerja yang kurang maksimal.

Dari beberapa permasalahan dalam kinerja guru di atas maka tugas pengawas sekolah dan kepala sekolah di sini sangat penting yaitu Pengawas sekolah melalui supervisi akademik dan kepala sekolah melalui kepemimpinannya diharapkan mampu membina dan membantu guru tersebut dalam memperbaiki dan meningkatkan kinerjanya. Hasil penelitian Hardono, dkk., (2017) menemukan bahwa supervisi akademik dan kepemimpinan kepala sekolah mempengaruhi kinerja guru.

Hasil pengamatan peneliti diperkuat oleh beberapa hasil studi lain, seperti hasil studi oleh Indrawati, dkk. (2015) menemukan bahwa kinerja guru di Madrasah Aliyah Kepenuhan Kabupaten Rokan Hulu dinilai masih rendah, diantaranya disebabkan beberapa masalah seperti kurangnya kedisiplinan guru, guru belum sepenuhnya melengkapi perangkat pembelajaran serta guru kurang menguasai media pembelajaran. Selain itu, hasil studi oleh Sari (2014) menemukan bahwa kinerja guru pada SDIT Nurul Falah Kecamatan Tambun Utara Kabupaten Bekasi dinilai tidak maksimal karena masih banyak guru yang mengajar secara konvensional tidak berdasarkan kompetensi yang dimiliki, guru mengerjakan evaluasi yang tidak sistematis sehingga tidak adanya keseimbangan kognitif, afektfif dan psikomotorik siswa, serta sikap guru kepada pemahaman karakteristik peserta didik tergolong minim sehingga guru masih terlihat tak hirau dengan murid. Padahal, menurut Rahardjo (2014:60) kualitas pendidikan di Sekolah Dasar salah satunya ditetapkan berdasarkan kualitas guru yang berdasarkan pengamatan menunjukkan 50\% guru Sekolah Dasar membutuhkan perhatian dalam upaya meningkatkan kualitas pengajaran dalam pengembangan profesinya. Sehubungan dengan uraian di atas serta hasil bacaan peneliti dalam beberapa jurnal ilmiah, maka menurut peneliti penting untuk mengadakan penelitian dengan judul "Pengaruh 
Supervisi Akademik Pengawas Sekolah dan Kepemimpinan Kepala Sekolah terhadap Kinerja Guru SMP Negeri Se-Kecamatan Banyuasin III".

\section{METODE PENELITIAN}

Penelitian ini akan dilaksanakan di SMP Negeri Se-Kecamatan Banyuasin III. Penelitian ini direncanakan berlangsung mulai dari bulan Februari sampai dengan Mei 2020. Penelitian ini menggunakan pendekatan kuantitatif dengan metode survey. Populasi dalam penelitian ini adalah seluruh kepala sekolah dan guru pada SMP Negeri Se-Kecamatan Banyuasin III dengan jumlah sampel sebanyak 70 orang guru termasuk kepala sekolah dari populasi berjumlah 165 responden. Instrumen penelitian yang digunakan berupa suatu set pertanyaan atau pernyataan awal yang berbentuk kusioner atau angket. Teknik analisis data menggunakan regresi linier sederhana dilanjutkan dengan Uji t dan regresi linier berganda dengan Uji F.

\section{HASIL PENELITIAN}

Berdasarkan penelitian yang telah dilakukan terhadap masing-masing variabel bebas dan variabel terikat, dari 70 angket pertanyaan atau pernyataan yang dibuat dengan menggunakan skala likert dengan rentang jawaban (1) sampai (5) yang peneliti sebarkan di SMP Negeri di Kecamatan Banyuasin III. Adapun hasil analisis penelitian menggunakan regresi sederhana dengan Uji $t$ dan analisis regresi berganda dengan Uji F dengan memakai alat bantu SPSS versi 22 for windows, maka diperoleh hasil sebagaimana akan disajikan pada Tabel di bawah ini.

Tabel 1. Hasil Analisis Uji t Variabel Supervisi Akademik Pengawas Sekolah (X1) Terhadap Kinerja Guru (Y)

\begin{tabular}{|c|c|c|c|c|c|c|}
\hline \multicolumn{2}{|c|}{ Model } & \multicolumn{2}{|c|}{$\begin{array}{c}\text { Unstandardized } \\
\text { Coefficients }\end{array}$} & \multirow{2}{*}{$\begin{array}{c}\text { Standardized } \\
\text { Coefficients } \\
\text { Beta }\end{array}$} & \multirow[t]{2}{*}{$\mathrm{T}$} & \multirow[t]{2}{*}{ Sig. } \\
\hline & & $\mathrm{B}$ & Std. Error & & & \\
\hline \multirow[t]{6}{*}{1} & (Constant) & - & 6,799 & & - & 146 \\
\hline & & 9,990 & & & 1,469 & \\
\hline & supervisi & ,737 & ,086 &, 632 & 8,532 & ,000 \\
\hline & akademik & & & & & \\
\hline & & & & & & \\
\hline & sekolah & & & & & \\
\hline
\end{tabular}


Berdasarkan output pada Tabel 1.1 di atas, maka diperoleh nilai signifikan sebesar 0,000 lebih kecil dari 0,05 sehingga $H o$ ditolak. Selain itu, nilai thitung 8,532 lebih besar dari nilai $t_{\text {tabel }} 1,995$ sehingga dapat disimpulkan bahwa Ha diterima. artinya ada pengaruh yang signifikan pengaruh supervisi akademik pengawas sekolah terhadap kinerja guru SMP Negeri Se-Kecamatan Banyuasin III.

\section{Tabel 1. Hasil Analisis Uji t Variabel Kepemimpinan Kepala Sekolah $\left(\mathbf{X}_{2}\right)$ Terhadap Kinerja Guru (Y)}

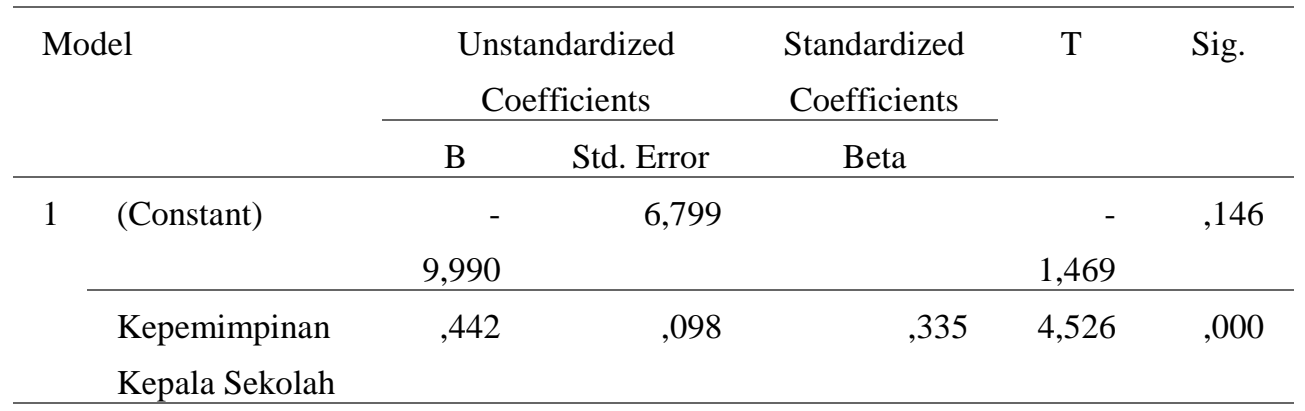

Berdasarkan output pada Tabel 1.2 di atas, maka diperoleh nilai signifikan sebesar 0,000 lebih kecil dari 0,05 sehingga $H o$ ditolak. Selain itu, nilai thitung 4,526 lebih besar dari nilai $t_{\text {tabel }} 1,995$ sehingga dapat disimpulkan bahwa Ha diterima. artinya ada pengaruh yang signifikan pengaruh kepemimpinan kepala sekolah terhadap kinerja guru SMP Negeri SeKecamatan Banyuasin III.

Tabel 3. Hasil Analisis Uji F Variabel Supervisi Akademik Pengawas Sekolah $\left(\mathrm{X}_{2}\right)$ dan Kepemimpinan Kepala Sekolah $\left(X_{2}\right)$ Terhadap Kinerja Guru (Y)

\begin{tabular}{llrrrrr}
\hline \multirow{2}{*}{ Model } & \multicolumn{1}{l}{$\begin{array}{c}\text { Sum of } \\
\text { Squares }\end{array}$} & Df & \multicolumn{1}{c}{$\begin{array}{c}\text { Mean } \\
\text { Square }\end{array}$} & F & Sig. \\
\hline \multirow{2}{*}{1} & Regression & 2206,146 & 2 & 1103,073 & 112,910 &, $000^{\mathrm{b}}$ \\
\cline { 2 - 7 } & Residual & 654,554 & 67 & 9,769 & & \\
\cline { 2 - 7 } & Total & 2860,700 & 69 & & & \\
\hline
\end{tabular}

Berdasarkan output pada Tabel 1.3 di atas, maka diperoleh nilai signifikan sebesar 0,000 lebih kecil dari 0,05 sehingga $H o$ ditolak. Selain itu, nilai thitung 112,910 lebih besar dari nilai $t_{\text {tabel }}$ 3,13 artinya ada pengaruh yang signifikan supervisi akademik pengawas sekolah dan kepemimpinan kepala sekolah terhadap kinerja guru SMP Negeri Se-Kecamatan Banyuasin III. Untuk mengetahui seberapa besar pengaruh variabel independen terhadap variabel dependen secara simultan dapat dilihat pada tabel model summary sebagai berikut. 
Tabel 4. Koefisien Determinasi

\begin{tabular}{ccccc}
\hline $\begin{array}{c}\text { Mod } \\
\text { el }\end{array}$ & $\mathrm{R}$ & $\begin{array}{c}\mathrm{R} \\
\text { Square }\end{array}$ & $\begin{array}{c}\text { Adjusted R } \\
\text { Square }\end{array}$ & $\begin{array}{c}\text { Std. Error of } \\
\text { the Estimate }\end{array}$ \\
\hline 1 &, $878^{\mathrm{a}}$ &, 771 &, 764 & 3,126 \\
\hline
\end{tabular}

Berkaitan dengan hasil perhitungan koefisien determinan yang terdapat pada Tabel 1.4 dapat diperoleh dari nilai $R$ Square sebesar 0,771 . Hal ini menunjukkan bahwa persentase sumbangan pengaruh variabel supervisi akademik pengawas sekolah dan kepemimpinan kepala sekolah secara bersama-sama terhadap kinerja guru sebesar $77,1 \%$ dan sisanya $29,9 \%$ dipengaruhi oleh faktor lainnya yang bukan menjadi variabel ini.

\section{PEMBAHASAN}

Berdasarkan hasil penelitian yang dikemukakan di atas, maka diketahui sebagai berikut.

\section{Pengaruh Supervisi Akademik Pengawas Sekolah Terhadap Kinerja Guru}

Supervisi akademik pengawas sekolah adalah kegiatan berupa bantuan dan bimbingan yang diberikan oleh pengawas sekolah dalam rangka meningkatkan kinerja dan kemampuan pengelolaan pembelajaran guru sehingga akan mendorong peningkatan prestasi belajar peserta didik yang pada akhirnya dapat meningkatkan mutu pendidikan. Supervisi yang harus dilakukan oleh pengawas sekolah diantaranya supervisi akademik yang berhubungan dengan aspek proses pembelajaran. Dan supervisi manajerial, yang berhubungan dengan aspek pengelolaan dan administrasi sekolah.

Supervisi akademik merupakan salah satu kegiatan dalam mengembangkan kemampuan guru untuk mencapai tujuan program sekolah, dan hasil supervisi akademik berfungsi sebagai sumber informasi bagi peningkatan kinerja guru. Oleh karena itu supervisi akademik yang dilakukan oleh pengawas sekolah memberikan peran yang sangat penting dalam meningkatkan dan mengembangkan kemajuan sekolah terutama dalam meningkatkan kinerja guru. Guru merupakan salah satu faktor dalam menentukan keberhasilan pendidikan, dengan demikian adanya supervisi akademik di sekolah dapat memberikan perubahan pada pendididikan.

Hal ini dapat dilihat berdasarkan tabel statistik deskriptif variabel supervisi akademik pengawas sekolah yang diperoleh, menunjukkan bahwa nilai mean lebih besar daripada nilai standar deviasi. Selanjutnya data supervisi akademik pengawas sekolah dihitung 
menggunakan teknik pengukuran kategori yang terdiri dari sangat baik, baik, cukup baik, kurang, dan sangat kurang. Dari hasil analisis yang didapat dijelaskan bahwa supervisi akademik pengawas sekolah menunjukkan bahwa supervisi akademik pengawas sekolah termasuk dalam kategori baik.

Selain itu, dari hasil analisis data menunjukkan pula bahwa nilai signifikan lebih kecil dari nilai koefisien sehingga Ho ditolak. Selain itu, nilai thitung lebih besar dari nilai ttabel sehingga dapat disimpulkan bahwa Ha diterima. artinya ada pengaruh yang signifikan pengaruh supervisi akademik pengawas sekolah terhadap kinerja guru SMP Negeri SeKecamatan Banyuasin III. Besarnya nilai yang diperoleh dalam penelitian ini semakin jelas membuktikan bahwa supervisi akademik pengawas sekolah berpengaruh signifikan terhadap kinerja guru.

Hasil penelitian ini didukung oleh penelitian terdahulu yang dilakukan oleh Aminuddin tentang "Pengaruh Kepemimpinan Kepala Sekolah dan Pengawasan Sekolah terhadap Kinerja Guru dalam Mewujudkan Prestasi Belajar Pendidikan Agama Islam” pada tahun 2017 menyatakan bahwa pengawasan pengawas sekolah berpengaruh positif secara signifikan terhadap kinerja guru. Kemudian hasil penelitian Ramadhan tentang "Pengaruh Pelaksanaan Supervisi Akademik Pengawas Sekolah dan Supervisi Kepala Sekolah terhadap Kinerja Guru SMK Negeri di Kabupaten Majene" pada tahun 2017 menyatakan bahwa supervisi akademik pengawas sekolah berpengaruh secara signifikan terhadap kinerja guru sebesar. Selanjutnya Heriyanto (2013) mengungkapkan "Supervisi Akademik Pengawas Sekolah Guru SMA di Kabupaten Kepahiang (Studi Deskriptif Kualitatif Tentang Supervisi Akademik)", inti dari tesis saudara Taba heriyanto adalah Pengawas sekolah memiliki andil dalam melaksanakan pengawasan akademik yakni menilai dan membina guru dalam rangka mempertinggi kualitas proses pembelajaran yang dilaksanakannya, sehingga kualitas hasil belajar peserta juga semakin baik. Dapat disimpulkan bahwa supervisi akademik oleh pengawas sekolah memberikan kontribusi dan pengaruh yang signifikan terhadap kinerja guru dan mutu pendidikan sekolah. Sehingga peran supervisi akademik oleh pengawas sekolah harus tetap dilakukan dengan tujuan untuk memberikan perubahan baik kepada kepala sekolah, guru dan sekolah itu sendiri yang nantinya akan berdampak pada peserta didik.

\section{Pengaruh Kepemimpinan Kepala Sekolah Terhadap Kinerja Guru}

Kepemimpinan kepala sekolah merupakan salah satu faktor yang dapat mempengaruhi kinerja guru di sekolah. Setiap guru dituntut untuk menunjukkan kinerjanya 
yang baik dan berkualitas. Banyak hal yang dapat mempengaruhi peningkatan kinerja guru di sekolah, salah satu diantaranya adalah teladan seorang pemimpin di sekolah yang dalam hal ini adalah kepemimpinan kepala sekolah. Kepala sekolah memiliki peranan yang dominan dalam suatu sekolah diantaranya memimpin, mengatur dan mengayomi pengikutnya serta menyelesaikan masalah-masalah yang timbul di lingkungan sekolah. Kepala sekolah bertanggung jawab terhadap maju-mundurnya kualitas pendidikan di sekolah yang menjadi tempat tugasnya. Kepemimpinan kepala sekolah juga memiliki andil yang sangat penting dalam menentukan arah dan kebijakan sekolah. Bahkan lebih dari itu, kepemimpinan kepala sekolah sangat mempengaruhi eksistensi sekolah tersebut. Termasuk dalam upaya meningkatkan kinerja guru, juga tidak terlepas dari peran kepemimpinan kepala sekolah. Dengan adanya kepemimpinan yang efektif, maka sekolah akan lebih maju sehingga guruguru akan lebih semangat dalam melakukan aktivitas di sekolah. Kepala sekolah merupakan pimpinan di sekolah yang mengatur jalannya pendidikan. Oleh karena itu kepala sekolah menjadi teladan bagi guru-guru di sekolah, sehingga dituntut memberikan sesuatu yang positif dalam memimpin. Dengan demikian kinerja guru akan lebih meningkat.

Hal ini dapat dilihat berdasarkan tabel statistik deskriptif variabel Kepemimpinan Kepala Sekolah (X1) yang diperoleh, menunjukkan bahwa nilai mean lebih besar daripada nilai standar deviasi. Selanjutnya data kepemimpinan kepala sekolah di hitung menggunakan teknik pengukuran kategori yang terdiri dari sangat baik, baik, cukup baik, kurang, dan sangat kurang. Dari hasil yang didapat dijelaskan bahwa kepemimpinan kepala sekolah termasuk dalam kategori baik. Selain itu, dari hasil analisis data juga menunjukkan pula bahwa nilai thitung ebih besar dari nilai ttabel dan nilai signifikan lebih kecil dari nilai koefisien sehingga Ho ditolak. Dengan membandingkan nilai thitung dan ttabel diketahui nilai thitung lebih besar dari nilai ttabel sehingga dapat disimpulkan bahwa Ha diterima. artinya ada pengaruh yang signifikan pengaruh kepemimpinan kepala sekolah terhadap kinerja guru SMP Negeri Se-Kecamatan Banyuasin III. Besarnya nilai yang diperoleh dalam penelitian ini semakin jelas membuktikan bahwa kepemimpinan kepala sekolah berpengaruh signifikan terhadap kinerja guru.

Hasil penelitian ini didukung oleh penelitian terdahulu yang dijelaskan oleh Utomo dan Sunarti tentang "Pengaruh Komite Sekolah, Kepemimpinan, dan Supervisi Akademik Kepala Sekolah terhadap Kinerja Guru SD” pada tahun 2014 menyatakan bahwa ada pengaruh yang positif dan signifikan komite sekolah, supervisi akademik dan kepemimpinan kepala sekolah terhadap kinerja guru. 
Kemudian penelitian Aminuddin tentang "Pengaruh Kepemimpinan Kepala Sekolah dan Pengawasan Sekolah terhadap Kinerja Guru dalam Mewujudkan Prestasi Belajar Pendidikan Agama Islam” pada tahun 2017 menyatakan bahwa pengawasan pengawas sekolah berpengaruh positif secara signifikan terhadap kinerja guru sebesar. Selanjutnya penelitian yang dilakukan Ismail (2017) dengan hasil yang mendeskripsikan bahwa kinerja mengajar guru, kompensasi guru, motivasi kerja guru, dan kepemimpinan kepala sekolah berada pada kategori tinggi. Kepemimpinan kepala sekolah memberikan pengaruh langsung terhadap kinerja mengajar guru dan secara tidak langsung berpengaruh terhadap kinerja mengajar guru. Pengaruh tidak langsung melalui kompensasi guru dan melalui motivasi kerja guru. Sementara sisanya dipenaruhi oleh variabel lain. Sementara itu hasil penelitian yang diungkap oleh Ishaq, dkk., (2016) dengan mengemukakan hasil bahwa kepemimpinan kepala sekolah SMA Negeri 4 Wira Bangsa Meulaboh dan SMA Neferi 3 Meulaboh mampu meningkatkan kinerja guru di masing-masing sekolah. Hal ini terbukti dari kurikulum, kesiswaan, sarana dan prasarana serta prestasi belajar siswa berjalan dengan baik sesuai standar kinerja guru. Tanggapan dan respon guru terhadap pendekatan kepemimpinan yang dialkukan kepala sekolah di SMA Negeri 4 Wira Bangsa Meulaboh dan SMA Negeri 3 Meulaboh cukup baik. Dengan demikian, kepemimpinan kepala sekolah memiliki pengaruh terhadap kinerja guru sehingga kinerja guru tidak lepas dari pengaruh kepemimpinan kepala sekolah. Karena semakin baik kepemimpinan kepala sekolah maka semakin meningkatkan kinerja guru dalam melaksanakan tugas sebagai pendidik.

\section{Pengaruh Supervisi Akademik Pengawas Sekolah dan Kepemimpinan Kepala Sekolah Terhadap Kinerja Guru}

Supervisi akademik pengawas sekolah dan kepemimpinan kepala sekolah merupakan komponen yang dapat mempengaruhi kinerja guru dalam pendidikan. Komponen tersebut tentu saja berdampak pada hasil kerja guru jika dilaksanakan sesuai dengan prosedur yang sudah ditetapkan. Supervisi memberikan bimbingan terhadap kepala sekolah dan guru yang berdampak pada kemajuan sekolah, sedangkan kepemimpinan kepala sekolah memberikan kontribusi terhadap kegiatan guru di sekolah sehingga kedua aspek ini dapat saling mempengaruhi terhadap kinerja guru di sekolah. Dalam penelitian ini variabel supervisi akademik pengawas sekolah dan kepemimpinan kepala sekolah secara bersama-sama berpengaruh terhadap peningkatan kinerja guru. Berdasarkan output nilai thitung lebih besar dari nilai ttabel yang artinya ada pengaruh yang signifikan supervisi akademik pengawas sekolah dan kepemimpinan kepala sekolah terhadap kinerja guru SMP Negeri Se-Kecamatan 
Banyuasin III. Kemudian diperoleh dari hasil nilai R Square yang menunjukkan bahwa persentase sumbangan pengaruh variabel supervisi akademik pengawas sekolah dan kepemimpinan kepala sekolah secara bersama-sama terhadap kinerja guru tergolong baik.

Angka-angka sumbangan efektif variabel independen terhadap nilai variabel dependen tersebut yang sudah dijelaskan adalah merupakan hasil analisis data di lapangan yang merefleksikan tingkat keefektifan pelaksanaan supervisi akademik pengawas sekiolah dan kepemimpinan kepala sekolah terhadap kinerja guru SMP Negeri Se-Kecamatan Banyuasin III. Temuan penelitian ini mengungkapkan bahwa supervisi akademik pengawas sekolah dan kepemimpinan kepala sekolah memiliki nilai pengaruh yang signifikan antar satu dengan lainnya terhadap kinerja guru.

Faktor penting yang berpengaruh terhadap meningkatnya kinerja guru, yaitu supervisi akademik pengawas sekolah. Adanya pelaksanaan supervisi akademik yang dilakukan oleh pengawas sekolah, maka guru memiliki kesempatan untuk meningkatkan kompetensi yang dimilikinya. Implementasi supervisi akademik oleh pengawas mempunyai tugas untuk memberikan bimbingan kepada guru, khususnya dalam meningkatkan kinerja yang dimiliki oleh guru. Oleh sebab itu, kehadiran seorang pengawas sangat dinantikan dalam upaya meningkatkan kinerja guru di sekolah. Sutisna dalam Sagala (2009: 229) menjelaskan bahwa supervisi merupakan suatu usaha yang ditujukan kepada penyediaan kepemimpinan bagi para guru dan tenaga kependidikan lain dalam perbaikan pengajaran, yang melibatkan stimulus pertumbuhan profesional dan perkembangan dari para guru, seleksi dan revisi tujuan pendidikan, bahan pengajaran, metode mengajar, dan evaluasi pengajaran. Oleh sebab itu, supervisi mampu memberikan pengaruh positif terhadap kinerja guru. Hasil penelitian ini didukung pula oleh hasil penelitian yang dilakukan oleh Ramadhan (2017) yang menjelaskan bahwa supervisi akademik pengawas sekolah berpengaruh secara signifikan terhadap kinerja guru di sekolah.

Selain faktor supervisi akademik pengawas sekolah, kinerja guru dipengaruhi pula oleh faktor kepemimpinan kepala sekolah. Menurut Rahayu, dkk., (2014: 99) menerangkan kepemimpinan kepala sekolah yaitu menggerakkan, mengarahkan, membimbing, memberi teladan, melindungi, dan memberi bantuan terhadap sumber daya manusia di sekolah. Artinya kepemimpinan kepala sekolah memberikan pengaruh terhadap kinerja guru di sekolah. Karena kepala sekolah adalah pimpinan di sekolah yang mengatur maju mundurnya pendidikan di sekolah tersebut. Sebagaimana yang dijelaskan oleh Septiana, dkk (2013: 109) bahwa kepemimpinan kepala sekolah memiliki pengaruh terhadap kinerja guru sehingga 
kinerja guru tidak lepas dari pengaruh kepemimpinan kepala sekolah. Karena semakin baik kepemimpinan kepala sekolah maka semakin meningkatkan kinerja guru dalam melaksanakan tugas sebagai pendidik.

Hal ini terbukti dari hasil penelitian Ngiode (2016) dari hasil penelitiannya diperoleh hasil yang menunjukkan bahwa terdapat pengaruh positif dan signifikan kepemimpinan kepala sekolah terhadap kinerja guru. Selain itu, hasil penelitian serupa yang dilakukan oleh Sulistiya (2013) menunjukkan bahwa kepemimpinan kepala sekolah berpengaruh signifikan terhadap kinerja guru. Dengan demikian kepemimpinan kepala sekolah memegang peranan yang sangat penting dalam kinerja guru guna menjalankan tugasnya dengan optimal sehingga tujuan pendidikan diharapkan dapat tercapai.

\section{SIMPULAN}

Berdasarkan analisis data dan pengujian hipotesis dapat diambil kesimpulan sebagai berikut: (1) Ada pengaruh supervisi akademik pengawas sekolah terhadap kinerja guru SMP Negeri Se-Kecamatan Banyuasin III. Artinya supervisi akademik pengawas sekolah sebaiknya dilaksanakan secara rutin oleh pengawas sekolah terhadap guru. Karena supervisi mampu mendorong dalam meningkatkan kinerja guru., (2) Ada pengaruh kepemimpinan kepala sekolah terhadap kinerja guru SMP Negeri Se-Kecamatan Banyuasin III. Artinya kepemimpinan yang bijaksana akan meningkatkan kinerja guru, sehingga kepemimpinan dapat memberi hal positif apabila dilaksanakan secara efektif oleh kepala sekolah., (3) Ada pengaruh supervisi akademik pengawas sekolah dan kepemimpinan kepala sekolah secara bersama-sama terhadap kinerja guru SMP Negeri Se-Kecamatan Banyuasin III. Artinya supervisi dan kepemimpinan harus diperhatikan dalam upaya untuk menjalankan tujuan pendidikan agar tercapai secara optimal.

\section{REFERENSI}

Ahmad, S. 2016. Ketahanmalangan Kepemimpinan Kepala Sekolah. Yogyakarta: Deepublish.

Aminuddin, A. 2017. Pengaruh Kepemimpinan Kepala Sekolah dan Pengawasan Pengawas Sekolah terhadap Kinerja Guru dalam Mewujudkan Prestasi Belajar Pendidikan Agama Islam. Jurnal Pendidikan Universitas Garut, 11 (1), 88-96.

Bada, I. A. 2012. Correlates of Supervisory Strategies and Quality Education in Secondary Schools in Oyo State, Nigeria. International Journal of Learning and Development, 2 (3). 
Hardono., Haryono., \& Yusuf, A. 2017. Kepemimpinan Kepala Sekolah, Supervisi Akademik, dan Motivasi Kerja dalam Meningkatkan Kinerja Guru. Journal Educational Management, 6 (1), 26-33.

Harapan, E. 2018. Pembiayaan Pendidikan. Palembang: NoerFikri Offset.

Heriyanto, T. 2013. Supervisi Akademik Pengawas Sekolah Guru SMA di Kabupaten Kepahiang (Studi Deskriptif Kualitatif Tentang Supervisi Akademik). Tesis, Universitas Bengkulu.

Indrawati., Lestari, R., \& Lubis, R, R. 2015. Kinerja Guru terhadap Motivasi Belajar Siswa Madrasah Aliyah Kepenuhan Kabupaten Rokan Hulu. Jurnal Ilmiah Mahasiswa FKIP Prodi Biologi, 1 (1), 1-5.

Ishaq, Yusrizal, Bahrun. 2016. Kepemimpinan Kepala Sekolah Dalam Meningkatkan Kinerja Guru Pada SMA Negeri 4 Wira Bangsa Meulaboh Dan SMA Negeri 3 Meulaboh. Jurnal Administrasi Pendidikan pp. 32- 45.

Ismail, Taufik. 2017. Kepemimpinan, Kompensasi, Motivasi Kerja, dan Kinerja Guru SD Negeri. Jurnal Administrasi Pendidikan, 24 (1).

Kant, R. 2014. A Study of Effect of Demographical Factors on Role Performance of Secondary School Teachers in India. Mevlana International Journal of Education, 4 (2).

Kompas. Com. 2014. Berita Buruk Pendidikan Indonesia. Diakses 15 Mei 2019. https://edukasi.kompas.com/read/2014/12/02/18365971/Berita.Buruk.Pendidikan.Indo nesia.

Mutakin, T. Z. 2013. Pengaruh Kompetensi, Kompensasi, dan Latar Belakang Terhadap Kinerja Guru. Jurnal Formatif, 3 (2), 145-156.

Ngiode, Syafrin. 2016. Pengaruh Kepemimpinan Kepala Sekolah, Motivasi Kerja dan Disiplin Kerja terhadap Kinerja Guru MTs.N Batudaa Kabupaten Gorontalo. Tadbir: Jurnal Manajemen Pendidikan Islam, 4 (2).

Peraturan Menteri Pendidikan Nasional Republik Indonesia. No. 13 Tahun 2007 tentang Standar Kepala Sekolah/Madrasah. Lembaran Negara RI Tahun 2007. Jakarta: SekretariatNegara.

Peraturan Pemerintah Republik Indonesia No. 19 Tahun 2005 tentang Standar Nasional Pendidikan. Lembaran Negara RI Tahun 2005, No. 41. Jakarta: Sekretariat Negara.

Peraturan Pemerintah Republik Indonesia. No. 74 Tahun 2008 tentang Guru. Lembaran Negara RI Tahun 2008, No. 4941. Jakarta: Sekretariat Negara. 
Rahayu, Sri, Sutama, dan Sabar Narimo. 2014. Kepemimpinan Kepala Sekolah dan Kedisiplinan Guru SMP N Kota Surakarta. Jurnal Manajemen Pendidikan. 9 (2), $97-$ 107.

Rahardjo, S. 2014. The Effect of Competence, Leadership and Work Environment Towards Motivation and its Impact on The Performance of Teacher of Elementary School in Surakarta City, Central Java, Indonesia. International Journal of Advanced Research in Management and Social Sciences, 3 (6).

Ramadhan, A. 2017. Pengaruh Pelaksanaan Supervisi Akademik Pengawas Sekolah dan Supervisi Kepala Sekolah terhadap Kinerja Guru SMK Negeri di Kabupaten Majene. Journal of Educational Science and Technology, 3 (2), 136-144.

Sagala, Syaiful. 2009. Administrasi Pendidikan Kontemporer. Bandung: Alfabeta.

Sari, Z. I. 2014. Hubungan Kompetensi Pedagogik Guru dengan Kinerja Mengajar Guru di SDIT Nurul Falah Kecamatan Tambun Utara Kabupaten Bekasi. Jurnal Pedagogik, 2 (1), 47-53.

Septiana, Roslena., Ngadiman \& Ivada, E. 2013. Pengaruh Kepemimpinan Kepala Sekolah dan Motivasi Kerja Terhadap Kinerja Guru SMP Negeri Wonosari. Jurnal Pendidikan (Jupe) UNS, 2 (1), 107-118.

Srinalia. 2015. Faktor-Faktor Penyebab Rendahnya Kinerja Guru dan Korelasi nya terhadap Pembinaan Siswa: Studi Kasusdi SMAN 1 Darul Imarah Aceh Besar. Jurnal Ilmiah DIDAKTIKA, 15 (2), 193-207.

Sulistiya, Mukhamad. 2013. Pengaruh Kepemimpinan Kepala Sekolah Terhadap Kinerja Guru. Jurnal Ilmiah Pendidikan Ekonomi IKIP Veteran Semarang. 1 (2).

Tesfaw, T. A., \& Hofman, R. H. 2014. Relationship between instructional supervision and professional development. The International Education Journal: Comparative Perspectives, 13 (1).

Tobari. 2016. Membangun Budaya Organisasi Pada Instansi Pemerintahan. Yogyakarta: Deepublish.

Undang-Undang Republik Indonesia. No. 14 Tahun 2005 tentang Guru dan Dosen. Lembaran Negara RI Tahun 2005, No. 4586. Jakarta: Sekretariat Negara.

Utomo, N. P., \& Sunarti. 2014. Pengaruh Komite Sekolah, Kepemimpinan, dan Supervisi Akademik Kepala Sekolah terhadap Kinerja Guru SD. Jurnal Sosialita, 1 (1), 31-42. 